\title{
Functional Properties of Butter Oil Made from Bovine Milk with Experimentally Altered Fat Composition ${ }^{1}$
}

\author{
G. Ortiz-Gonzalez, ${ }^{\star 2}$ R. Jimenez-Flores, ${ }^{\star 3}$ D. R. Bremmer, $\dagger^{4}$ J. H. Clark, $†$ E. J. DePeters, $\ddagger$ \\ S. J. Schmidt, ${ }^{\star}$ and J. K. Drackleyt ${ }^{5}$ \\ *Department of Food Science and Human Nutrition, and \\ †Department of Animal Sciences, University of Illinois, Urbana 61801 \\ ‡Department of Animal Science, University of California, Davis 95616
}

\begin{abstract}
Modification of milk fat composition might be desirable to alter manufacturing characteristics or produce low saturated fat dairy products that more closely meet consumer dietary preferences. The aim of this research was to evaluate functional properties of butter oil obtained from milks with fat composition modified by altering the profile of long-chain fatty acids (FA) absorbed from the small intestine of cows. A control and 5 mixtures of long-chain free FA were infused into the abomasum of lactating dairy cows in a $6 \times 6$ Latin square design with 21-d periods. Treatments were 1) control (no FA infused), 2) mostly saturated $\mathrm{FA}\left(\mathrm{C}_{16}: \mathrm{C}_{18}=0.72\right.$ ), 3) low-linoleic palm FA $\left(\mathrm{C}_{16}: \mathrm{C}_{18}=0.85\right)$, 4) palm FA $\left.\left(\mathrm{C}_{16}: \mathrm{C}_{18}=0.72\right), 5\right)$ soy FA $\left(\mathrm{C}_{16}: \mathrm{C}_{18}=0.10\right)$, and 6$)$ highpalmitic soy $\mathrm{FA}\left(\mathrm{C}_{16}: \mathrm{C}_{18}=0.68\right)$. All treatments included meat solubles and Tween 80 as emulsifiers. Solid fat content (from 0 to $40^{\circ} \mathrm{C}$ ), melting point, and force at fracture were determined in butter oil. Milk fat from cows infused with palm FA (treatment 4) exhibited functionality equal to or better than control butter oil. Infusion with palm FA increased amounts of triglyceride (TG) fractions with 48,52 , and 54 carbon numbers but decreased TG with $32,34,36$, and 42 carbon numbers. Infusion with soy FA increased TG with 26,38 , 40,52 , and 54 carbon numbers but decreased TG with 34,42 , and 46 carbons. Infusion of the mostly saturated FA increased TG with $38,50,52$, and 54 carbon num-

\footnotetext{
Received February 21, 2007.

Accepted June 27, 2007.

${ }^{1}$ Supported by state and federal funds appropriated to the Illinois

${ }^{2}$ Current address: Carrera de Ingeniería Agroindustrial, Universi-

${ }^{3}$ Current address: California Polytechnic State University, San

${ }^{4}$ Current address: Vita Plus Corp., Greenwood, WI 54437.

${ }^{5}$ Corresponding author: drackley@uiuc.edu
} Agricultural Experiment Station through CSREES regional research projects W-181 and W-1181. The triglyceride analysis of milk fat was supported by the California Dairy Research Foundation, Davis, CA. dad Autónoma de San Luis Potosí, San Luis Potosí, S.L.P., CP 78290, Mexico. Luis Obispo, CA 93407.
\end{abstract}

bers but decreased TG with 32,34 , and 42 carbon numbers. These TG groups were consistently correlated with functional properties of butter oils from different treatments. The content of palmitic acid is important for maintaining functionality in the presence of increased polyunsaturated FA. The composition of milk fat may be able to be optimized through nutritional manipulation of diets for dairy cows if the optimal composition of FA and TG is defined for a particular dairy product.

Key words: butter oil, fatty acid, triglycerides, functional properties

\section{INTRODUCTION}

Milk fat is important for flavor and the unique mouthfeel of dairy products. However, the nutritional image, relatively high price, and seasonal and functional variability make milk fat unsuitable for many food applications. The dairy industry is challenged to provide competitive food products that are nutritionally consistent with consumer demands (O'Donnell, 1989).

Intake of saturated fat has been associated with coronary heart disease in humans (Wilke and Clandinin, 2005). Hypercholesterolemic effects of saturated fats are largely due to the fatty acids (FA) $\mathrm{C}_{14: 0}$ and $\mathrm{C}_{16: 0}$; in contrast, $\mathrm{C}_{18: 0}$ and $\mathrm{C}_{18: 1 \text { icis-9 }}$ are neutral or beneficial with respect to plasma cholesterol (Bonanome and Grundy, 1988; Parthasarathy et al., 1990; Woodside and Kromhout, 2005). Supplemental fats rich in $\mathrm{C}_{18} \mathrm{FA}$ and low in $\mathrm{C}_{16: 0}$ in the diet of dairy cows can substantially increase $\mathrm{C}_{18: 0}$ and $\mathrm{C}_{18: 1 c i s-9}$ and decrease $\mathrm{C}_{16: 0}$ in milk fat (Grummer, 1991). Noakes et al. (1996) demonstrated that such alteration of the FA profile of dairy products in the diets of typical Western populations represents a potential strategy to lower the risk of coronary heart disease without appreciable change in customary eating patterns.

Use of milk fat in foods is frequently limited by functional incompatibilities with other ingredients (Kaylegian and Lindsay, 1994; Hillbrick and Augustin, 2002). 
The rheological (melting) properties of milk fat influence numerous aspects of character and quality of dairy products (Fearon, 1988; Palmquist et al., 1993). Physical properties, including melting point and solid fat index or solid fat content, are among the most important predictors of milk fat functionality. Solid fat content is related to the melting properties of milk fat in the human mouth during mastication (Ali and Dimick, 1994). Thermal profiles obtained using differential scanning calorimetry (DSC) show the major melting species of milk fat triglycerides (TG) and phase transitions between crystal forms (Kaylegian and Lindsay, 1994; Michalski et al., 2004; Lopez et al., 2005).

Increased unsaturation of the FA in milk fat by greater pasture intake (Couvreur et al., 2006) or addition of unprotected fats or oils to the cows' diet lowers the melting point of milk fat (Banks et al., 1989; Enjalbert et al., 1997, 2000; Chouinard et al., 1998). Much of this effect arises from mammary desaturation of $\mathrm{C}_{18: 0}$, produced during ruminal biohydrogenation of dietary unsaturated FA, to $\mathrm{C}_{18: 1 c i s-9}$ (Grummer, 1991; Palmquist et al., 1993). Butter produced from such milks may be softer but still possess acceptable flavor and texture (Middaugh et al., 1988; Stegeman et al., 1992; Couvreur et al., 2006). Feeding protected unsaturated oils (Banks, 1991) or calcium salts of vegetable oils (Chouinard et al., 1998) to cows resulted in milk fat with a higher ratio of unsaturated to saturated FA and, hence, a softer milk fat. In some instances, however, increased unsaturation of milk fat caused flavor defects, affected the size of milk fat globules, and altered milk fat crystallization, which changed the functional properties of milk fat (Precht et al., 1984; Shi et al., 2001; Hillbrick and Augustin, 2002). For example, increased polyunsaturated FA (PUFA), such as $\mathrm{C}_{18: 2}$, in milk fat created body and flavor defects in cheese (Wong et al., 1982).

Technological advances in interesterification and fractionation have increased opportunities to manipulate physical properties of milk fat and increase butter spreadability (Boudreau and Arul, 1993; Kaylegian and Lindsay, 1994; German and Dillard, 1998). The importance of the stereospecific position of FA in TG molecules is well recognized (Banks et al., 1989; Fearon et al., 1994); TG structure affects the release of flavor constituents, alters melting and crystallization behaviors, and contributes to hypercholesterolemic effects (Jensen et al., 1991; Kermasha et al., 1993). However, precise relationships among TG and FA composition and functional properties are not well defined.

Milk fat with altered FA and TG profiles might provide new opportunities for commercial use and consumer acceptance. However, to capitalize on this potential, relationships among FA profile, TG composition, physical properties of milk fat, and resulting functional-
Table 1. Fatty acid (FA) composition ( $\mathrm{g} / 100 \mathrm{~g}$ of total FA) of infusate mixtures $^{1}$

\begin{tabular}{lcrrrrr}
\hline & \multicolumn{6}{c}{ Infusate $^{2}$} \\
\cline { 2 - 7 } FA & Control & \multicolumn{1}{c}{ SFA } & PFALL & PFA & SOFA & SOFAHP \\
\hline $\mathrm{C}_{12: 0}$ & 0.39 & 0.01 & 0.02 & 0.02 & 0.01 & 0.02 \\
$\mathrm{C}_{14: 0}$ & 1.75 & 0.04 & 1.54 & 0.13 & 0.16 & 0.13 \\
$\mathrm{C}_{16: 0}$ & 3.77 & 40.09 & 39.86 & 40.06 & 9.04 & 40.20 \\
$\mathrm{C}_{16: 1}$ & 4.46 & 0.11 & 3.78 & 0.26 & 0.20 & 0.22 \\
$\mathrm{C}_{18: 0}$ & 1.25 & 40.03 & 3.21 & 3.14 & 3.26 & 2.48 \\
$\mathrm{C}_{18: 1 \text { cis }-9}$ & 60.50 & 15.43 & 40.57 & 36.66 & 25.81 & 17.37 \\
$\mathrm{C}_{18: 1 \text { trans }}$ & $\mathrm{ND}$ & $\mathrm{ND}$ & 5.08 & 6.51 & $\mathrm{ND}$ & ND \\
$\mathrm{C}_{18: 2}$ & 0.45 & 0.01 & 2.21 & 9.02 & 54.09 & 35.43 \\
$\mathrm{C}_{18: 3}$ & $\mathrm{ND}$ & $\mathrm{ND}$ & 0.19 & 0.54 & 6.37 & 4.27 \\
$\mathrm{C}_{16}: \mathrm{C}_{18}$ & 0.13 & 0.72 & 0.85 & 0.72 & 0.10 & 0.68 \\
\hline
\end{tabular}

${ }^{1}$ From Bremmer et al. (1998).

${ }^{2}$ Treatment infusates were control (no FA infused), SFA (mostly saturated FA), PFALL (low linoleic palm FA), PFA (palm FA), SOFA (soy FA), and SOFAHP (high palmitic soy FA).

${ }^{3} \mathrm{ND}=$ not detected.

ity of milk fat in dairy products need to be better characterized. The objective of this study was to evaluate the effects of abomasal infusion of defined FA mixtures on functional properties of the resulting butter oil. Relationships between milk fat composition and TG distribution with functional characteristics of butter oil were characterized.

\section{MATERIALS AND METHODS}

\section{Experimental Design and Treatments}

Cannulation, housing, and management of cows, and experimental treatments were described previously by Bremmer et al. (1998). The experimental design was a $6 \times 6$ Latin square with 21 -d periods. The 6 treatments were continuous abomasal infusions of 1) control: 168 g/d of meat solubles (Milk Specialties Co., Dundee, IL) $+10.6 \mathrm{~g} / \mathrm{d}$ of Tween 80 (Sigma Chemical Co., St. Louis, MO); 2) saturated FA (SFA): control + $450 \mathrm{~g} / \mathrm{d}$ of mostly saturated FA (prilled FFA from Energy Booster 100; Milk Specialties Co.); 3) palm oil FA low in linoleic acid (PFALL): control + $450 \mathrm{~g} / \mathrm{d}$ of FA approximating lowlinoleic palm oil FFA (Henkel Corp., Emery Division, Cincinnati, OH); 4) palm oil FA (PFA): control +450 g/d of FFA approximating palm oil (Henkel Corp.); 5) soybean oil FA (SOFA): control $+450 \mathrm{~g} / \mathrm{d}$ of soy FFA (Henkel Corp.); and 6) soy FA high in palmitic acid (SOFAHP): control $+450 \mathrm{~g} / \mathrm{d}$ of FFA approximating composition of high-palmitic soy oil (Henkel Corp.). The FA composition of the infusates (Bremmer et al., 1998) is shown in Table 1 . The control infusate served as a carrier for the FA emulsions in the FA treatments. Infusion emulsions were prepared by homogenization and infused as described by Bremmer et al. (1998), 
and effects of treatments on DMI, milk yield, and milk composition were reported therein.

\section{Compositional and Functional Analysis}

Milk Samples. Milk was sampled from p.m. and a.m. milkings on d 17, 19, and 21 of each period. Samples for analyses of total solids and fat were taken when the milk had been heated to $32.2^{\circ} \mathrm{C}$ before separation of cream. Fat was calculated from the solid fat content in a microwave oven (LabWave 9000, CEM Corporation, Matthews, NC). From each milking, 2 random samples were analyzed for fat content by the Babcock method (AOAC, 1995) to verify determination by the microwave method. For comparative purposes, a commercial sample of margarine was purchased at a local grocer.

Butter Oil. Milk was heated to $32.2^{\circ} \mathrm{C}$ and cream was separated in an open centrifugal cream separator. Cream was standardized with its own skim milk to a fat content of $33 \%$ and pasteurized $\left(62.7^{\circ} \mathrm{C}\right.$ for $\left.30 \mathrm{~min}\right)$ in 18.9-L stainless steel buckets set in a small waterjacketed pasteurizer. The cream was cooled to $4.4^{\circ} \mathrm{C}$ by placing the cans in cold water after pasteurization. The cream was held for $24 \mathrm{~h}$ at approximately $4.4^{\circ} \mathrm{C}$ before being whipped until butter granules formed and churning occurred. After eliminating most of the butter milk, the remaining water was removed by warming the samples in a commercial microwave oven ( $30 \mathrm{~s}$ at high power), and separating the water and protein phases by centrifugation. Samples of liquid butter oil were poured into Petri dishes and set to solidify in a refrigerator at $4.4^{\circ} \mathrm{C}$.

\section{Physical Evaluation of Butter Oil}

Heating thermograms were obtained by using DSC (Modulated DSC model 2920; TA-Instruments Inc., New Castle, DE). The instrument was calibrated with distilled deionized water and indium standards. Samples of butter oil and the margarine sample $(10 \pm 2 \mathrm{mg})$ were hermetically sealed in alodined aluminum pans (TA-Instruments Inc.). The sample cell was purged with He gas $(25 \mathrm{~mL} / \mathrm{min})$ and cooled with $\mathrm{N}_{2}$ gas $(150 \mathrm{~mL} /$ min) during the analysis. Samples were held at $60^{\circ} \mathrm{C}$ for $3 \mathrm{~min}$ to melt any crystal present, cooled to $-60^{\circ} \mathrm{C}$ at $10^{\circ} \mathrm{C} / \mathrm{min}$, held for $3 \mathrm{~min}$, and then heated to $60^{\circ} \mathrm{C}$ at $10^{\circ} \mathrm{C} / \mathrm{min}$ to obtain a melting profile (Kaylegian and Lindsay, 1994). The cooling and heating rate was selected based on reference method Cj 1-94 (AOCS, 1998). The melting point (completion of melt) was taken as the temperature at the end of the peak for the high melting fraction (AOCS, 1998). Solid fat content was calculated by dividing the partial area under the melting curve by the total area from -40 to $40^{\circ} \mathrm{C}$ multiplied by 100 . Solid fat content from 0 to $40^{\circ} \mathrm{C}$ was calculated at $5^{\circ} \mathrm{C}$ intervals.

Hardness of butter oil and margarine was determined by constant-speed penetrometry, which involved measurements of the force required to push a cylindrical punch moving at constant speed of $2 \mathrm{~mm} / \mathrm{s}$ for a penetration depth of $5 \mathrm{~mm}$. Hardness was measured with a texture analyzer (model TA-XT2; Texture Technologies Corp., Scarsdale, NY) fitted with a TA-55 cylindrical punch probe. Samples were removed from the refrigerator $\left(4.4^{\circ} \mathrm{C}\right)$ and stabilized for $5 \mathrm{~min}$ at room temperature $\left(20^{\circ} \mathrm{C}\right)$. The force at fracture was used as a response variable for comparison among treatments. Three penetration tests were conducted in each of the samples in Petri dishes. Results for force at fracture were expressed in newtons.

\section{Fatty Acid Analysis}

Milk fat was analyzed for FA composition as described by Bremmer (1995). Briefly, milk fat obtained from the Babcock procedure (AOAC, 1995) was stored frozen $\left(-20^{\circ} \mathrm{C}\right)$ until analyzed $(<6 \mathrm{mo})$. Fat was thawed, transferred to a clean tube, and FA were methylated by direct acid-catalyzed transesterification (Sukhija and Palmquist, 1988). Fatty acid methyl esters were separated by GC using a 30-m SP-2380 (Supelco, Bellefonte, PA) column as described by Sukhija and Palmquist (1988). Milk fat standards (Nu-Chek Prep, Elysian, $\mathrm{MN}$ ) were used to identify FA based on retention times.

\section{Triglyceride Analysis in Butter Oil}

Butter oil samples were diluted to $10 \%$ (wt/vol) with 2,2,4-trimethylpentane. Analysis of TG was conducted in a gas chromatograph (model 5890, Series II; Hewlett Packard, Avondale, PA), using a high-temperature, aluminum-clad, fused-silica capillary column (25 m length, $0.25 \mathrm{~mm}$ i.d., $0.1 \mu \mathrm{m}$ film thickness) with a liquid phase of bonded methyl 65\% phenyl silicone (Quadrex Corp., New Haven, CT). The column temperature was increased from $250^{\circ} \mathrm{C}$ at $5^{\circ} \mathrm{C} / \mathrm{min}$ to a final temperature of $365^{\circ} \mathrm{C}$. The injector temperature was $400^{\circ} \mathrm{C}$ and the injection split ratio was 40:1. Helium was used as the carrier gas at a flow rate of $1.0 \mathrm{~mL} / \mathrm{min}$. Standard monoacid and mixed-chain TG (Nu-Chek Prep), as well as hydrogenated milk fat samples, were used to determine the retention times of specific TG. The TG peaks were quantified using area percentages. The area for each TG group (i.e., C number) was expressed as a percentage of the total area for the sample.

\section{Statistical Analysis}

For each variable, data were subjected to ANOVA for a Latin square design using the GLM procedure in SAS 
Table 2. Major fatty acid composition ( $\mathrm{g} / 100 \mathrm{~g}$ of total milk fat) of milkfat from cows abomasally infused with fatty acid mixtures ${ }^{1}$

\begin{tabular}{lccccccc}
\hline & \multicolumn{7}{c}{ Infusate } \\
\cline { 2 - 6 } Fatty acid & Control & SFA & PFALL & PFA & SOFA & SOFAHP & SEM \\
\hline $\mathrm{C}_{4}$ to $\mathrm{C}_{10}$ & $8.53^{\mathrm{d}}$ & $7.53^{\mathrm{bcd}}$ & $5.74^{\mathrm{a}}$ & $6.82^{\mathrm{ac}}$ & $7.75^{\mathrm{bcd}}$ & $6.71^{\mathrm{ab}}$ & 0.22 \\
$\mathrm{C}_{12: 0}$ & $2.84^{\mathrm{b}}$ & $2.03^{\mathrm{a}}$ & $1.94^{\mathrm{a}}$ & $1.81^{\mathrm{a}}$ & $2.09^{\mathrm{a}}$ & $2.05^{\mathrm{a}}$ & 0.11 \\
$\mathrm{C}_{14: 0}$ & $10.34^{\mathrm{c}}$ & $8.61^{\mathrm{b}}$ & $8.50^{\mathrm{ab}}$ & $7.83^{\mathrm{a}}$ & $7.71^{\mathrm{a}}$ & $7.78^{\mathrm{a}}$ & 0.30 \\
$\mathrm{C}_{14: 1}$ & 1.31 & 1.09 & 1.19 & 1.03 & 2.01 & 0.79 & 0.47 \\
$\mathrm{C}_{15: 0}$ & $1.24^{\mathrm{d}}$ & $0.98^{\mathrm{c}}$ & $0.95^{\mathrm{bc}}$ & $0.87^{\mathrm{ab}}$ & $0.77^{\mathrm{a}}$ & $0.83^{\mathrm{a}}$ & 0.04 \\
$\mathrm{C}_{16: 0}$ & $31.68^{\mathrm{c}}$ & $30.41^{\mathrm{cd}}$ & $31.13^{\mathrm{de}}$ & $29.31^{\mathrm{bc}}$ & $21.60^{\mathrm{a}}$ & $29.22^{\mathrm{b}}$ & 0.45 \\
$\mathrm{C}_{16: 1}$ & $1.49^{\mathrm{b}}$ & $1.59^{\mathrm{b}}$ & $2.05^{\mathrm{c}}$ & $1.56^{\mathrm{b}}$ & $0.96^{\mathrm{a}}$ & $1.09^{\mathrm{a}}$ & 0.15 \\
$\mathrm{C}_{17: 0}$ & $0.62^{\mathrm{d}}$ & $0.74^{\mathrm{e}}$ & $0.53^{\mathrm{c}}$ & $0.51^{\mathrm{bc}}$ & $0.47^{\mathrm{a}}$ & $0.48^{\mathrm{ab}}$ & 0.02 \\
$\mathrm{C}_{18: 0}$ & $9.44^{\mathrm{c}}$ & $10.88^{\mathrm{d}}$ & $8.15^{\mathrm{a}}$ & $8.05^{\mathrm{a}}$ & $9.06^{\mathrm{b}}$ & $8.76^{\mathrm{ab}}$ & 0.33 \\
$\mathrm{C}_{18: 1 \text { cis-9 }}$ & $16.76^{\mathrm{a}}$ & $20.44^{\mathrm{b}}$ & $23.47^{\mathrm{c}}$ & $24.32^{\mathrm{c}}$ & $18.65^{\mathrm{ab}}$ & $17.03^{\mathrm{a}}$ & 0.70 \\
$\mathrm{C}_{18: 1 \text { trans }}$ & $0.62^{\mathrm{a}}$ & $0.69^{\mathrm{a}}$ & $0.66^{\mathrm{a}}$ & $1.15^{\mathrm{b}}$ & $0.59^{\mathrm{a}}$ & $0.61^{\mathrm{a}}$ & 0.21 \\
$\mathrm{C}_{18: 2}$ & $2.43^{\mathrm{a}}$ & $2.39^{\mathrm{a}}$ & $3.13^{\mathrm{b}}$ & $4.24^{\mathrm{c}}$ & $14.53^{\mathrm{e}}$ & $11.10^{\mathrm{d}}$ & 0.24 \\
$\mathrm{C}_{18: 3}$ & $0.40^{\mathrm{b}}$ & $0.35^{\mathrm{a}}$ & $0.40^{\mathrm{b}}$ & $0.47^{\mathrm{c}}$ & $1.48^{\mathrm{c}}$ & $1.20^{\mathrm{d}}$ & 0.02 \\
\hline
\end{tabular}

${ }^{\mathrm{a}-\mathrm{e}}$ Means within a row not sharing a common superscript are significantly different $(P<0.05)$.

${ }^{1}$ Treatment infusates were control (no fatty acid infused), SFA (mostly saturated fatty acids), PFALL (low linoleic palm fatty acids), PFA (palm fatty acids), SOFA (soy fatty acids), and SOFAHP (high palmitic soy fatty acids)

(version 6.01, SAS Institute, Inc., Cary, NC) as described in Bremmer et al. (1998). Means were separated using multiple pairwise comparisons when the treatment $F$-test was significant $(P \leq 0.05)$. Least squares means were calculated and are presented throughout.

During wk 3 of the sixth period, the cow receiving SOFA developed foot problems and was removed from the experiment. All data from this cow for period 6 were excluded from the statistical analyses.

\section{RESULTS AND DISCUSSION}

\section{Effect of FA Infusion on Milk FA Composition}

Changes in milk FA composition resulting from abomasal FA infusion (Table 2) generally were as predicted from the profile of infused FA (Palmquist et al., 1993; Chilliard et al., 2000, 2001). The content of FA from $\mathrm{C}_{4}$ to $\mathrm{C}_{10}$ was decreased relative to control by all FA treatments (from $-11.2 \%$ for SFA, not significantly different from control, to $-32.3 \%$ for SOFAHP). Contents of $\mathrm{C}_{12: 0}$ and $\mathrm{C}_{14: 0}$ also were less than for control when cows were infused with $\mathrm{FA}$. The content of $\mathrm{C}_{16: 0}$ was slightly lower than control in milk from cows infused with FA (from -1.7\% for PFALL to $-7.8 \%$ for SOFAHP), except when SOFA was infused, in which case $\mathrm{C}_{16: 0}$ was decreased markedly (31.8\% lower than control). Content of $\mathrm{C}_{18: 0}$ was higher than control for cows infused with SFA (15.3\%), but was decreased by other FA treatments.

Except for $\mathrm{C}_{14: 1}$, the long-chain unsaturated $\mathrm{FA}$ in milk fat were altered by FA infusions compared with control (Table 2). The content of $\mathrm{C}_{18: 1 c i s-9}$ was increased by all FA mixtures except SOFAHP, with increases ranging from $11.2 \%$ (SOFA) to $45.1 \%$ (PFA). Content of $\mathrm{C}_{18: 2}$ increased markedly for PFALL (28.8\%), PFA (74.5\%), SOFA (498\%), and SOFAHP (357\%). Content of $\mathrm{C}_{18: 3}$ was decreased by SFA, but was increased $17.5 \%$ by PFA, $270 \%$ by SOFA, and $200 \%$ by SOFAHP. Unexpectedly, milk fat from cows infused with PFA had significantly greater contents of $\mathrm{C}_{18: 1 \text { trans }}$ (Table 2). The $\mathrm{C}_{18: 1 \text { trans }}$ isomers also were found in the PFA infusate (Bremmer et al., 1998) and thus presumably were transferred directly to milk fat.

The ratio between long-chain saturated FA and longchain unsaturated FA (data not tabulated) decreased relative to control for all treatments in a range from $-14.1 \%$ (SFA) to $-55.2 \%$ (SOFA). The increased contents of PUFA resulting from treatments SOFA and SOFAHP were similar to those reported previously that increased the risk for developing rancidity and off-flavors in creams and other dairy products (Lin et al., 1996; Ashes et al., 1997).

\section{Effect of FA Infusion on Butter Oil TG Composition}

We observed significant differences in TG groups of milk fat when FA were infused compared with the control milk fat, and significant differences among FA treatments (Table 3). Infusion of SFA decreased the contents of $\mathrm{C}_{32}, \mathrm{C}_{34}$, and $\mathrm{C}_{42} \mathrm{TG}$, but increased contents of $\mathrm{C}_{38}, \mathrm{C}_{50}, \mathrm{C}_{52}$, and $\mathrm{C}_{54} \mathrm{TG}$. Infusion of PFALL or PFA decreased $\mathrm{C}_{32}, \mathrm{C}_{34}, \mathrm{C}_{36}$, and $\mathrm{C}_{42}$, but increased $\mathrm{C}_{48}, \mathrm{C}_{50}$, $\mathrm{C}_{52}$, and $\mathrm{C}_{54}$. The lower $\mathrm{C}_{18: 2}$ content of PFALL compared with PFA resulted in smaller amounts of $\mathrm{C}_{26}$, $\mathrm{C}_{52}$, and $\mathrm{C}_{54} \mathrm{TG}$, but increased $\mathrm{C}_{42}$ and $\mathrm{C}_{46}$. Infusion of PUFA (SOFA) increased $\mathrm{C}_{26}, \mathrm{C}_{38}, \mathrm{C}_{40}, \mathrm{C}_{52}$, and $\mathrm{C}_{54}$, but decreased $\mathrm{C}_{34}, \mathrm{C}_{36}$, and $\mathrm{C}_{46}$. The presence of increased 
Table 3. Triglyceride (TG) composition of milk fat ( $\mathrm{g} / 100 \mathrm{~g}$ fat) from cows abomasally infused with fatty acid mixtures ${ }^{1}$

\begin{tabular}{|c|c|c|c|c|c|c|c|}
\hline \multirow{2}{*}{$\begin{array}{l}\text { TG carbon } \\
\text { number } \\
\text { group }\end{array}$} & \multicolumn{6}{|c|}{ Infusate } & \multirow[b]{2}{*}{ SEM } \\
\hline & Control & SFA & PFALL & PFA & SOFA & SOFAHP & \\
\hline $\mathrm{C}_{26}$ & $1.22^{\mathrm{a}}$ & $1.28^{\mathrm{ab}}$ & $1.33^{\mathrm{ab}}$ & $1.57^{\mathrm{c}}$ & $1.39^{\mathrm{b}}$ & $1.35^{\mathrm{ab}}$ & 0.05 \\
\hline $\mathrm{C}_{28}$ & 1.78 & 1.78 & 1.81 & 2.10 & 2.12 & 1.95 & 0.13 \\
\hline $\mathrm{C}_{30}$ & 2.45 & 2.38 & 2.50 & 2.81 & 2.89 & 2.73 & 0.15 \\
\hline $\mathrm{C}_{32}$ & $4.90^{\mathrm{c}}$ & $4.04^{\mathrm{a}}$ & $4.21^{\mathrm{ab}}$ & $4.24^{\mathrm{ab}}$ & $4.49^{\mathrm{abc}}$ & $4.68^{\mathrm{bc}}$ & 0.17 \\
\hline $\mathrm{C}_{34}$ & $9.83^{\mathrm{c}}$ & $8.96^{\mathrm{b}}$ & $8.24^{\mathrm{ab}}$ & $8.14^{\mathrm{a}}$ & $8.66^{\mathrm{ab}}$ & $8.74^{\mathrm{ab}}$ & 0.26 \\
\hline $\mathrm{C}_{36}$ & $15.94^{\mathrm{c}}$ & $16.17^{\mathrm{c}}$ & $14.46^{\mathrm{ab}}$ & $14.00^{\mathrm{a}}$ & $14.40^{\mathrm{ab}}$ & $15.61^{\mathrm{bc}}$ & 0.39 \\
\hline $\mathrm{C}_{38}$ & $15.94^{\mathrm{a}}$ & $17.97^{\mathrm{bcd}}$ & $16.72^{\mathrm{ab}}$ & $16.94^{\mathrm{abc}}$ & $18.28^{\mathrm{cd}}$ & $18.37^{\mathrm{d}}$ & 0.47 \\
\hline $\mathrm{C}_{40}$ & $11.14^{\mathrm{ab}}$ & $11.42^{\mathrm{ab}}$ & $11.21^{\mathrm{ab}}$ & $11.09^{\mathrm{a}}$ & $14.97^{\mathrm{c}}$ & $12.10^{\mathrm{b}}$ & 0.34 \\
\hline $\mathrm{C}_{42}$ & $8.19^{\mathrm{d}}$ & $6.90^{\mathrm{b}}$ & $6.91^{\mathrm{b}}$ & $5.99^{\mathrm{a}}$ & $7.80^{\text {cd }}$ & $7.26^{\mathrm{bc}}$ & 0.27 \\
\hline $\mathrm{C}_{44}$ & 7.55 & 5.42 & 6.68 & 6.13 & 5.03 & 6.40 & 0.54 \\
\hline $\mathrm{C}_{46}$ & $7.98^{\mathrm{b}}$ & $7.26^{\mathrm{ab}}$ & $8.16^{\mathrm{b}}$ & $7.87^{\mathrm{b}}$ & $6.30^{\mathrm{a}}$ & $6.27^{\mathrm{a}}$ & 0.34 \\
\hline $\mathrm{C}_{48}$ & $7.04^{\mathrm{ab}}$ & $7.56^{\mathrm{bc}}$ & $8.64^{\mathrm{c}}$ & $8.52^{\mathrm{c}}$ & $5.82^{\mathrm{a}}$ & $6.86^{\mathrm{ab}}$ & 0.44 \\
\hline $\mathrm{C}_{50}$ & $4.51^{\mathrm{a}}$ & $6.03^{\text {bcd }}$ & $6.43^{\mathrm{cd}}$ & $6.97^{\mathrm{d}}$ & $5.06^{\mathrm{ab}}$ & $5.34^{\mathrm{abc}}$ & 0.41 \\
\hline $\mathrm{C}_{52}$ & $1.38^{\mathrm{a}}$ & $2.53^{\mathrm{bc}}$ & $2.42^{\mathrm{b}}$ & $3.22^{\mathrm{c}}$ & $2.43^{\mathrm{b}}$ & $2.12^{\mathrm{b}}$ & 0.23 \\
\hline $\mathrm{C}_{54}$ & $0.14^{\mathrm{a}}$ & $0.29^{b c}$ & $0.29^{\mathrm{bc}}$ & $0.42^{\mathrm{d}}$ & $0.36^{\mathrm{cd}}$ & $0.21^{\mathrm{ab}}$ & 0.04 \\
\hline
\end{tabular}

$\mathrm{C}_{16: 0}$ with PUFA (SOFAHP) negated some of these effects; high $\mathrm{C}_{16: 0}$ in SOFAHP resulted in contents of $\mathrm{C}_{40}$ and $\mathrm{C}_{54}$ that were lower than SOFA, but similar to controls. These TG groups were consistently correlated with functional properties exhibited by butter oils from different treatments, as discussed later.

Our results were generally similar to those reported by Banks et al. (1989), Fearon et al. (1994), and DePeters et al. (2001). Banks et al. (1989) and Fearon et al. (1994) found that supplementation of the diet with oils or commercial fat products decreased proportions of TG from $\mathrm{C}_{30}$ to $\mathrm{C}_{36}$ and $\mathrm{C}_{42}$ to $\mathrm{C}_{46}$, but increased $\mathrm{TG}$ from $\mathrm{C}_{50}$ to $\mathrm{C}_{54}$. DePeters et al. (2001) fed diets supplemented with canola oil or infused canola oil into either the rumen or abomasum. They found that TG from $\mathrm{C}_{32}$ to $\mathrm{C}_{36}$ and $\mathrm{C}_{42}$ to $\mathrm{C}_{44}$ decreased, whereas TG from $\mathrm{C}_{50}$ to $\mathrm{C}_{54}$ increased in response to supplemental oil with little difference due to route of administration. The TG from $\mathrm{C}_{32}$ to $\mathrm{C}_{36}$ and $\mathrm{C}_{42}$ to $\mathrm{C}_{44}$ are enriched with short-chain and medium-chain FA (Gresti et al., 1993); these FA are decreased by supplemental long-chain FA (Palmquist et al., 1993). In contrast, the $\mathrm{C}_{50}$ to $\mathrm{C}_{54} \mathrm{TG}$ predominantly contain FA of 16 or 18 carbons (Gresti et al., 1993). Consequently, changes observed by Banks et al. (1989) and DePeters et al. (2001), as well as our results, generally reflect the reduction in de novo synthesis of FA in the mammary gland and their replacement with $\mathrm{C}_{18}$ FA in milk fat TG (DePeters et al., 2001).

Triglycerides were grouped by carbon number and no attempt was made to quantify all individual molecular species that constitute each carbon number group. Qualitative results from the high-temperature gas chromatograph (data not shown) provide some insight into specific TG species that were altered by abomasal FA infusion. Changes in TG composition of individual carbon number peaks were observed because of the increase in unsaturated FA and decrease of short-chain FA in milk fat (Gresti et al., 1993). We noted, for example, a reduction in area of the 2 main peaks constituting $\mathrm{C}_{46} \mathrm{TG}$ (MPP and MOM, where $\mathbf{M}=$ myristic acid, $\mathbf{P}=$ palmitic acid, and $\mathbf{O}=$ oleic acid) for all FA treatments compared with the control. This reduction reflected the decreased percentages of $\mathrm{C}_{14: 0}$ and $\mathrm{C}_{16: 0}$ caused by FA infusion; the greatest decrease was for SOFA, which had the lowest contents of $\mathrm{C}_{14: 0}$ and $\mathrm{C}_{16: 0}$. For $\mathrm{C}_{48} \mathrm{TG}$, 3 main peaks could be identified (PPP, MOP, and MPL; $\mathbf{L}=$ linoleic acid). The first 2 peaks decreased for SOFA and SOFAHP, which was likely related to the decreased contents of $\mathrm{C}_{14: 0}$ and $\mathrm{C}_{16: 0}$ for SOFA and SOFAHP. The third peak (MPL) was greater for SOFAHP than for PFALL because of the increased amount of $\mathrm{C}_{18: 2}$ for SOFAHP. Peaks PPO and MOO for $\mathrm{C}_{50}$ TG and OOO for $\mathrm{C}_{54}$ TG increased when cows were infused with PFALL and PFA because of the greater content of $\mathrm{C}_{18: 1 c i s-9}$ with similar $\mathrm{C}_{16: 0}$ compared with control. Peaks including $\mathrm{C}_{18: 2}$, such as LPB ( $\mathbf{B}=$ butyric acid) at $\mathrm{C}_{38}$, LOB at $\mathrm{C}_{40}, \mathrm{MSL}\left(\mathbf{S}=\right.$ stearic acid) at $\mathrm{C}_{50}$, POL at $\mathrm{C}_{52}$, and SOL at $\mathrm{C}_{54}$ increased for SOFA and SOFAHP compared with controls.

\section{Effect of FA Infusion on Functional Properties of Butter Oil}

The heterogeneity and complexity of milk fat is reflected in its wide and variable melting range. Milk fat 
Table 4. Functional properties of butter oil from cows abomasally infused with fatty acid mixtures ${ }^{1}$

\begin{tabular}{|c|c|c|c|c|c|c|c|}
\hline \multirow[b]{2}{*}{ Variable } & \multicolumn{6}{|c|}{ Infusate } & \multirow[b]{2}{*}{ SEM } \\
\hline & Control & SFA & PFALL & PFA & SOFA & SOFAHP & \\
\hline $\mathrm{DSC}^{2}$ melting point, ${ }^{\circ} \mathrm{C}$ & $32.99^{\mathrm{a}}$ & $32.85^{\mathrm{a}}$ & $32.29^{\mathrm{ab}}$ & $31.47^{\mathrm{bc}}$ & $27.83^{\mathrm{d}}$ & $30.84^{\mathrm{bc}}$ & 0.36 \\
\hline Solid fat content at $5^{\circ} \mathrm{C}, \%$ & $70.4^{\mathrm{ab}}$ & $71.9^{\mathrm{a}}$ & $65.6^{\mathrm{abc}}$ & $63.4^{\mathrm{c}}$ & $54.8^{\mathrm{d}}$ & $64.1^{\mathrm{bc}}$ & 1.3 \\
\hline Solid fat content at $20^{\circ} \mathrm{C}, \%$ & $31.0^{\mathrm{a}}$ & $30.6^{\mathrm{a}}$ & $31.3^{\mathrm{a}}$ & $31.5^{\mathrm{a}}$ & $15.4^{\mathrm{b}}$ & $26.4^{\mathrm{a}}$ & 1.4 \\
\hline Force at fracture, $\mathrm{N}$ & $16.3^{\mathrm{a}}$ & $15.3^{\mathrm{a}}$ & $8.6^{\mathrm{b}}$ & $5.8^{\mathrm{b}}$ & $5.0^{\mathrm{b}}$ & $8.2^{\mathrm{b}}$ & 1.0 \\
\hline
\end{tabular}

${ }^{\mathrm{a}-\mathrm{d}}$ Means within a row not sharing a common superscript are significantly different $(P<0.05)$.

${ }^{1}$ Treatment infusates were control (no fatty acid infused), SFA (mostly saturated fatty acids), PFALL (low linoleic palm fatty acids), PFA (palm fatty acids), SOFA (soy fatty acids), and SOFAHP (high palmitic soy fatty acids).

${ }^{2} \mathrm{DSC}=$ differential scanning calorimetry.

is completely liquid at $40^{\circ} \mathrm{C}$ and completely solid at $-40^{\circ} \mathrm{C}$ (Mulder and Walstra, 1974). Between these temperatures, milk fat exists as a mixture of crystals and liquid. According to Mulder and Walstra (1974), the degree of crystallinity or solid to liquid ratio is dependent on composition, state of dispersion, and temperature history. The cooling rate also has marked effects on crystallization behavior (Lopez et al., 2005). The melting point of milk fat is defined as the temperature at which milk fat becomes visually clear and free of crystals, and is approximately 32 to $36^{\circ} \mathrm{C}$ for "normal" milk fat.

Comparative results for the functional properties evaluated in butter oil are shown in Table 4, and correlations among functional properties are in Table 5 . Melting point as determined by DSC (Table 4) did not differ among control, SFA, and PFALL, but melting point for control and SFA differed from that for PFA, SOFA, and SOFAHP. In addition, PFALL and PFA were not significantly different and PFA was not different from SOFAHP. Only SOFA differed from all other treatments. Increases in $\mathrm{C}_{14: 0}$ and $\mathrm{C}_{16: 0}$ were directly correlated with increased melting point, whereas in- creased $\mathrm{C}_{18: 2}$ was associated with decreased melting point (Table 6). According to Kaylegian and Lindsay (1994), increases in short-chain FA and long-chain unsaturated FA with concurrent decreases in long-chain saturated FA resulted in milk fats with lowered melting points. In our case, potential effects of short-chain FA and $\mathrm{C}_{18: 1 c i s-9}$ were not as clear as the effects of $\mathrm{C}_{14: 0}$, $\mathrm{C}_{16: 0}$, and $\mathrm{C}_{18: 2}$ because of the marked differences in proportions of those FA among treatments. Melting point also was negatively correlated with $\mathrm{C}_{28}, \mathrm{C}_{30}, \mathrm{C}_{38}$, and $\mathrm{C}_{40} \mathrm{TG}$ (Table 7) because of the preponderance of short-chain FA and unsaturated FA in those TG (Gresti et al., 1993). In contrast, melting point was positively correlated with $\mathrm{C}_{44}, \mathrm{C}_{46}$, and $\mathrm{C}_{48} \mathrm{TG}$ (Table 7), because of the greater content of long-chain saturated FA in those TG.

Kaylegian et al. (1993) explained that melting point values give no indication of milk fat melting behavior over the temperature range preceding the final clear point. However, profiles of thermal behavior and solid fat content over a given temperature range can be used to predict the behavior at different stages of manufacturing, the cold-spreadability of butter, and some sen-

Table 5. Correlations among functional parameters of butter oil ${ }^{1}$

\begin{tabular}{|c|c|c|c|c|c|}
\hline Functional property & $\begin{array}{c}\text { Solid fat } \\
\text { content } \\
\text { at } 5^{\circ} \mathrm{C}\end{array}$ & $\begin{array}{l}\text { Solid fat } \\
\text { content } \\
\text { at } 20^{\circ} \mathrm{C}\end{array}$ & $\begin{array}{l}\text { Solid fat } \\
\text { content } \\
\text { at } 30^{\circ} \mathrm{C}\end{array}$ & $\begin{array}{l}\text { Solid fat } \\
\text { content } \\
\text { at } 35^{\circ} \mathrm{C}\end{array}$ & $\begin{array}{l}\text { Force at } \\
\text { fracture }\end{array}$ \\
\hline \multirow[t]{2}{*}{$\mathrm{DSC}^{2}$ melting point } & 0.760 & 0.789 & 0.838 & 0.807 & 0.404 \\
\hline & 0.0001 & 0.0001 & $<0.0001$ & $<0.0001$ & 0.018 \\
\hline \multirow[t]{2}{*}{ Solid fat content at $5^{\circ} \mathrm{C}$} & - & 0.822 & 0.854 & 0.761 & 0.432 \\
\hline & & $<0.0001$ & $<0.0001$ & $<0.0001$ & 0.011 \\
\hline \multirow[t]{2}{*}{ Solid fat content at $20^{\circ} \mathrm{C}$} & - & - & 0.942 & 0.815 & 0.198 \\
\hline & & & $<0.0001$ & $<0.0001$ & 0.26 \\
\hline \multirow{2}{*}{ Solid fat content at $30^{\circ} \mathrm{C}$} & - & - & - & 0.928 & 0.267 \\
\hline & & & & $<0.0001$ & 0.13 \\
\hline \multirow[t]{2}{*}{ Solid fat content at $35^{\circ} \mathrm{C}$} & - & - & - & - & 0.237 \\
\hline & & & & & 0.18 \\
\hline
\end{tabular}

${ }^{1}$ Top number is the Pearson correlation coefficient and the bottom number is the probability that the correlation differs from zero.

${ }^{2} \mathrm{DSC}=$ differential scanning calorimetry. 
Table 6. Correlations among butter oil functional parameters and fatty acid composition ${ }^{1}$

\begin{tabular}{lcllllllll}
\hline & \multicolumn{10}{c}{ Fatty acid } \\
\cline { 2 - 9 } Functional property & $\mathrm{C}_{4}$ to $\mathrm{C}_{10}$ & $\mathrm{C}_{12: 0}$ & $\mathrm{C}_{14: 0}$ & $\mathrm{C}_{16: 0}$ & $\mathrm{C}_{18: 0}$ & $\mathrm{C}_{18: 1 \text { cis-9 }}$ & $\mathrm{C}_{18: 1 \text { trans }}$ & $\mathrm{C}_{18: 2}$ & $\mathrm{C}_{18: 3}$ \\
\hline DSC $^{2}$ melting point & -0.132 & 0.147 & 0.424 & 0.815 & 0.038 & 0.022 & 0.056 & -0.733 & 0.022 \\
& 0.45 & 0.40 & 0.011 & $<0.0001$ & 0.83 & 0.90 & 0.75 & $<0.0001$ & 0.90 \\
Solid fat content at $5^{\circ} \mathrm{C}$ & 0.038 & 0.236 & 0.449 & 0.653 & 0.274 & -0.123 & -0.020 & -0.593 & -0.578 \\
& 0.83 & 0.17 & 0.007 & $<0.0001$ & 0.11 & 0.48 & 0.91 & 0.0002 & 0.0003 \\
Solid fat content at $20^{\circ} \mathrm{C}$ & -0.182 & 0.133 & 0.398 & 0.709 & -0.074 & 0.096 & -0.011 & -0.595 & -0.609 \\
& 0.30 & 0.44 & 0.018 & $<0.0001$ & 0.67 & 0.58 & 0.95 & 0.0002 & $<0.0001$ \\
Solid fat content at $30^{\circ} \mathrm{C}$ & -0.102 & 0.061 & 0.303 & 0.668 & 0.108 & 0.100 & 0.077 & -0.622 & -0.635 \\
& 0.56 & 0.73 & 0.077 & $<0.0001$ & 0.54 & 0.57 & 0.66 & $<0.0001$ & $<0.0001$ \\
Solid fat content at $35^{\circ} \mathrm{C}$ & -0.072 & 0.003 & 0.195 & 0.525 & 0.232 & 0.027 & 0.088 & -0.502 & -0.510 \\
& 0.68 & 0.99 & 0.26 & 0.001 & 0.18 & 0.88 & 0.62 & 0.002 & 0.002 \\
Force at fracture & 0.235 & 0.336 & 0.426 & 0.401 & 0.526 & -0.302 & 0.001 & -0.483 & -0.437 \\
& 0.18 & 0.052 & 0.012 & 0.019 & 0.001 & 0.082 & 0.99 & 0.004 & 0.010 \\
\hline
\end{tabular}

\footnotetext{
${ }^{1}$ Top number is the Pearson correlation coefficient and the bottom number is the probability that the correlation differs from zero.

${ }^{2} \mathrm{DSC}=$ differential scanning calorimetry.
}

sory properties such as melt-in-the-mouth characteristics. Thermal profiles of milk fat obtained using DSC are shown in Figures 1 and 2 and demonstrate the 3 major melting fractions. As the content of PUFA increased, the high-melting fraction decreased and the low- and mid-melting fractions increased. The lower $\mathrm{C}_{16: 0}$ content for SOFA than for SOFAHP clearly illustrates the effect of $\mathrm{C}_{16: 0}$ on the high-melting fraction; milk fat from SOFA showed only low- and mid-melting fractions. Milk fat from PFA was the only treatment that showed a proportionally lower mid-melting fraction, which likely explains its lower force of fracture and hence, greater plasticity (Kaylegian and Lindsay, 1994) compared with PFALL and SOFAHP.

Other typical differences among treatments could be observed from the cooling thermograms (Figure 3). Exothermic peaks are associated with crystallization phenomena of polymorphic forms. One main and well-defined peak occurred at about $6.3^{\circ} \mathrm{C}$. This peak existed as the only peak or with 1 or 2 smaller peaks at about 12 and $14.5^{\circ} \mathrm{C}$, respectively. With increased PUFA content, the main peak was shifted to a lower temperature $\left(4.8^{\circ} \mathrm{C}\right.$ for PFA and $2.3^{\circ} \mathrm{C}$ for SOFA). Fat from cows infused with SOFA exhibited just one broad peak. Evidently, peaks at 12 and $14.5^{\circ} \mathrm{C}$ were related to crystallization of some high melting TG fraction. This secondary peak was prominent for PFA, probably because of the relatively lower mid-melting fraction, and because of the greater content of $\mathrm{C}_{18: 1 \text { trans }}$ isomers that could be involved in a high melting TG fraction. The $\mathrm{C}_{18: 1 \text { trans }}$ isomers have a higher melting point than $\mathrm{C}_{18: 1 c i s-9}$, possibly promoting crystallization of a TG fraction represented in this peak.

Results for solid fat contents related to the heating thermograms are presented in Table 4 and Figure 4. The solid fat content of milk fat is a measurement of the percentage of solid milk fat in a sample at a selected temperature and was identified by Fearon (1988) as 1 of the 3 fundamental factors contributing to rheological properties of butter. A solid fat content profile for the milk fat sample can be generated by measurement of solid fat content over a selected temperature range. At $5^{\circ} \mathrm{C}$, control and SFA treatments had the greatest solid fat content and SOFA the least (Table 4). Milk fat from control, SFA, and PFALL treatments did not differ significantly from one another. Likewise, PFALL, PFA, and SOFAHP did not differ significantly from each other, but SOFA had the lowest solid fat content among all treatments. Similar to our results, Chouinard et al. (1998) found that supplemental calcium salts of vegetable oils decreased the proportion of solid fat at $5^{\circ} \mathrm{C}$. Fearon et al. (1994) fed a larger amount $(1.0 \mathrm{~kg} / \mathrm{d})$ of a fat supplement similar to SFA used in the present study and observed consistently higher solid fat content in milk fat compared with their control milk fat.

Similar to melting point, the solid fat content at $5^{\circ} \mathrm{C}$ was positively correlated with $\mathrm{C}_{14: 0}$ and $\mathrm{C}_{16: 0}$ and negatively correlated with $\mathrm{C}_{18: 2}$; however, $\mathrm{C}_{18: 3}$ also was negatively correlated with solid fat content (Table 6). Triglyceride groups associated negatively with solid fat content at $5^{\circ} \mathrm{C}$ were $\mathrm{C}_{26}, \mathrm{C}_{28}, \mathrm{C}_{30}, \mathrm{C}_{40}$, and $\mathrm{C}_{54}$ (Table 7), which contain mainly $\mathrm{C}_{18: 1 c i s-9}, \mathrm{C}_{18: 2}, \mathrm{C}_{18: 3}$, and shortchain FA (Gresti et al., 1993). Positive correlations were found between solid fat content at $5^{\circ} \mathrm{C}$ and $\mathrm{C}_{46}$ or $\mathrm{C}_{48}$ TG, which are particularly associated with $\mathrm{C}_{16: 0}$.

At $20^{\circ} \mathrm{C}$, solid fat content did not differ significantly among control, SFA, PFALL, PFA, and SOFAHP, but SOFA again showed the lowest solid fat content. The solid fat contents measured at all temperatures were highly correlated with each other and with the DSC melting point (Table 5). At $20^{\circ} \mathrm{C}, \mathrm{C}_{14: 0}$ and $\mathrm{C}_{16: 0}$ again were correlated positively, and $\mathrm{C}_{18: 2}$ and $\mathrm{C}_{18: 3}$ correlated 
negatively, with solid fat content (Table 6). Triglyceride groups negatively correlated with the solid fat content at this temperature were $\mathrm{C}_{28}, \mathrm{C}_{38}$, and $\mathrm{C}_{40}$, which are enriched in short-chain, $\mathrm{C}_{18: 2}$, and $\mathrm{C}_{18: 3} \mathrm{FA}$. The TG groups positively correlated with solid fat at $20^{\circ} \mathrm{C}$ were $\mathrm{C}_{44}, \mathrm{C}_{46}$, and $\mathrm{C}_{48}$, which are associated with $\mathrm{C}_{14: 0}$ and $\mathrm{C}_{16: 0}$ acids. When solid fat contents were measured at $30^{\circ} \mathrm{C}$ or $35^{\circ} \mathrm{C}$, the influence of $\mathrm{C}_{14: 0}$ lessened and $\mathrm{C}_{16: 0}$, $\mathrm{C}_{18: 2}$, and $\mathrm{C}_{18: 3}$ had the major influence (Table 6). These changes also were reflected in the greater inverse relationships between $\mathrm{C}_{30}$ and $\mathrm{C}_{32} \mathrm{TG}$ and solid fat content at the higher temperatures (Table 7).

Although not quantified by defined methodology, qualitative observations of samples of butter oil at $5^{\circ} \mathrm{C}$ showed that control and SFA were nonspreadable, brittle, and very plastic, whereas PFALL and SOFAHP were softer but still plastic and relatively difficult to spread. Treatment PFA showed increased spreadability compared with PFALL and SOFAHP, whereas SOFA was spreadable at refrigeration temperature. As a reference, a commercial margarine was more spreadable and nonplastic than butter oil from all treatments.

At $20^{\circ} \mathrm{C}$, butters from control and SFA were softer and spreadable, kept a good physical shape, and did not show melted fat. Butter from cows infused with SFA was slightly grainy. Butters from PFALL and PFA were very soft and spreadable, but even when they kept their physical shape, they were slightly oily because of the partial melting of some TG fractions. Comparatively, PFA was more grainy than PFALL, probably due to the presence of high melting crystals. As determined from the thermograms (Figures 1 and 2), PFA showed a more definite high-melting fraction and lower midmelting fraction than PFALL, and the presence of an extra crystalline form was evident even in the cooling thermograms (Figure 3). Finally, SOFAHP and SOFA were very oily at $20^{\circ} \mathrm{C}$ and lost their shape due to melting. The effect was more pronounced for SOFA than for SOFAHP. Both showed the largest low- and midmelting fractions on the thermograms, associated with the high content of low-melting PUFA. Although SOFA showed excellent spreadability under refrigeration conditions, it did not show good behavior at ambient temperatures. Similar to our results, Badings et al. (1976) reported that butter made from ripened cream with fat containing $12 \% \mathrm{C}_{18: 2}$ had good texture and spreadability at refrigerator temperature $\left(4^{\circ} \mathrm{C}\right)$, but at higher temperatures the butter was soft, weak, and poor in quality.

Hardness of butter is influenced by the total FA composition and the stereo-specific distribution of FA in TG molecules (DeMan, 1961). The results of penetrometry tests performed at $5^{\circ} \mathrm{C}$ showed a logarithmic decrease in force of fracture as the proportion of unsaturated FA in milk fat increased (Table 4). Treatments control and 


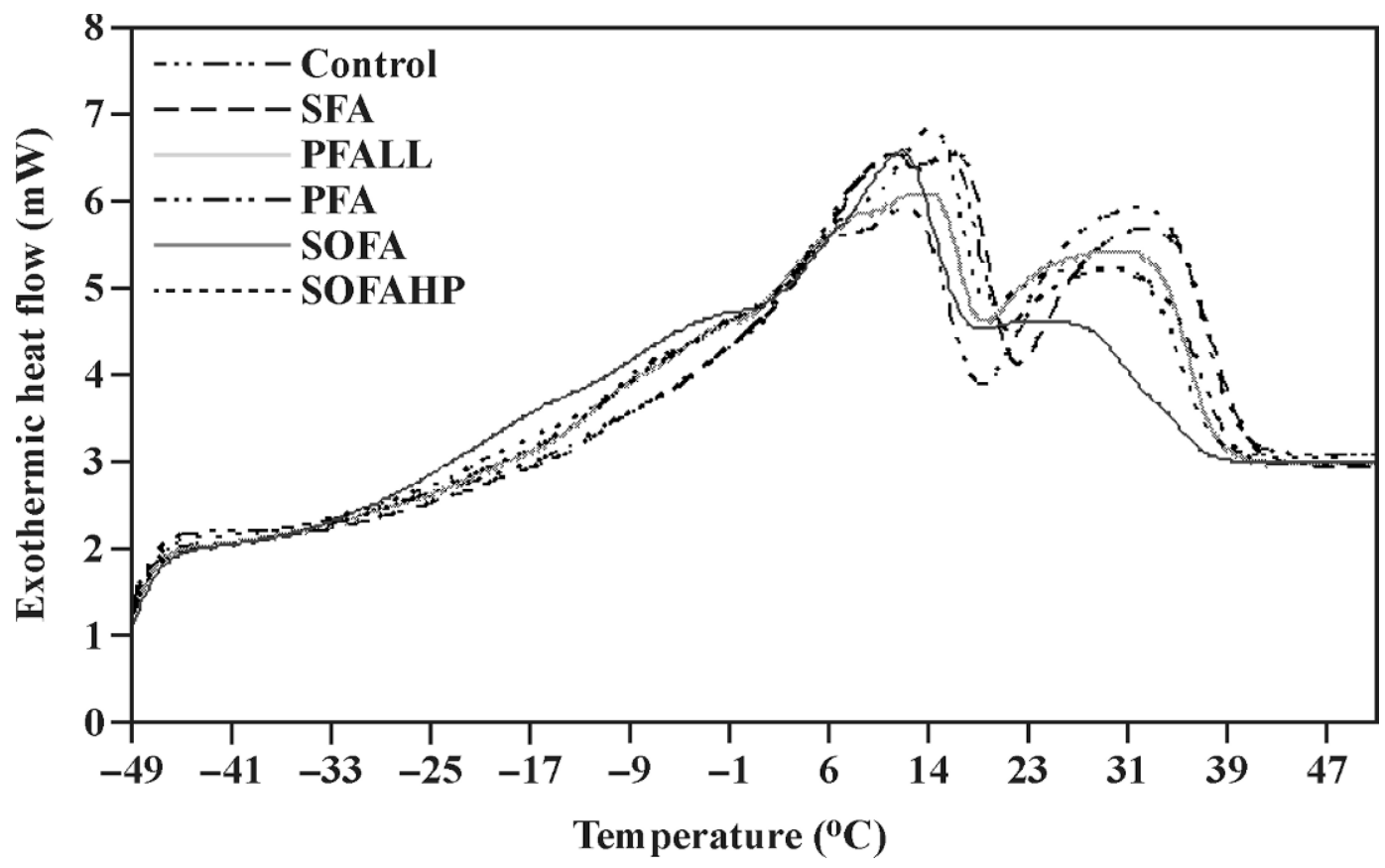

Figure 1. Average heating thermograms for butter oils prepared from milk of cows infused with different mixtures of fatty acids (SFA = saturated fatty acids, PFALL = low linoleic palm oil fatty acids, PFA = palm oil fatty acids, SOFA = soy oil fatty acids, SOFAHP = high palmitic soy oil fatty acids). To more clearly view individual treatment curves, thermograms are shifted in Figure 2.

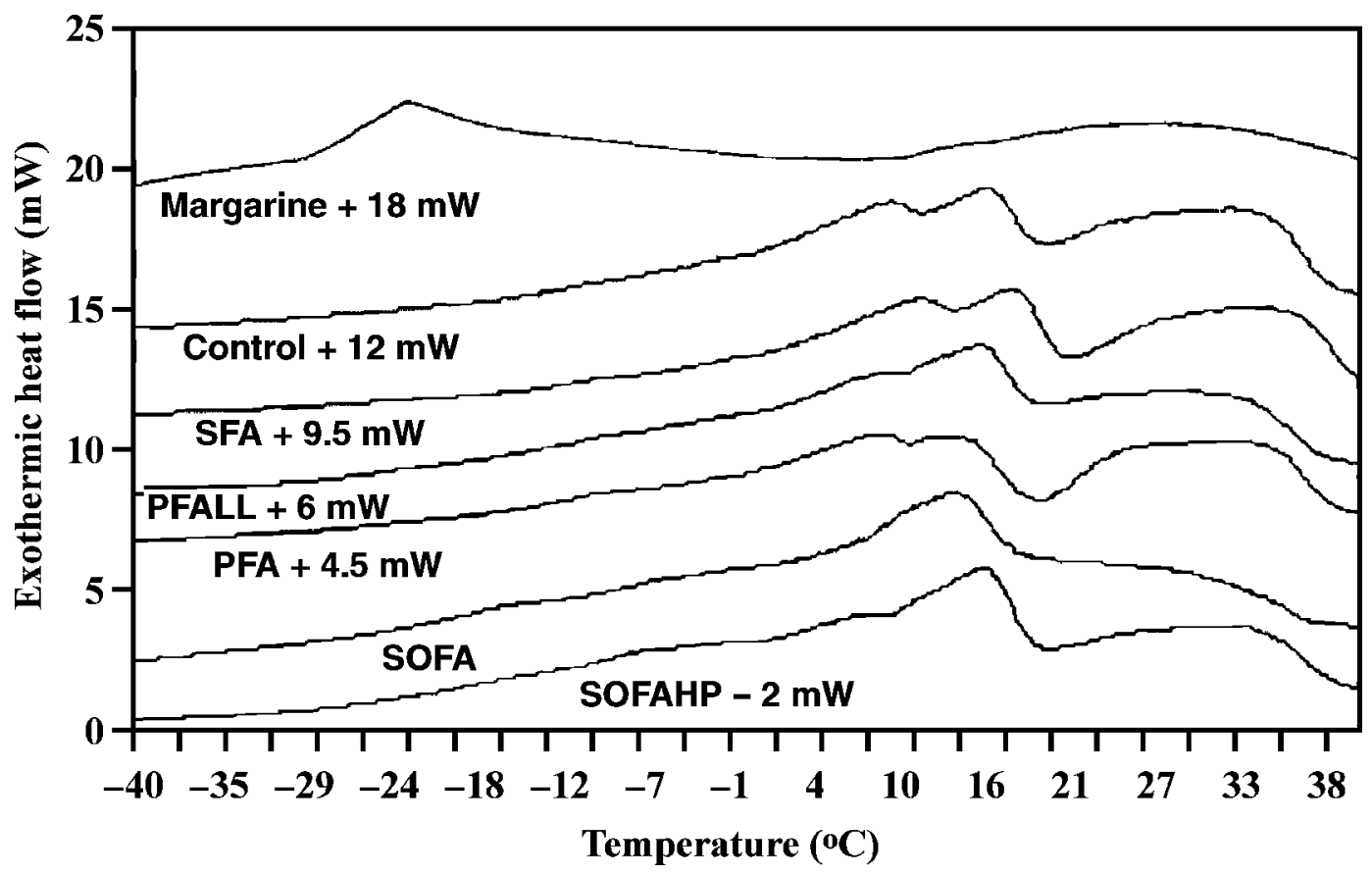

Figure 2. Shifted average heating thermograms for butter oil samples prepared from milk of cows abomasally infused with various fatty acid treatments $(\mathrm{SFA}=$ saturated fatty acids, PFALL = low linoleic palm oil fatty acids, PFA = palm oil fatty acids, SOFA = soy oil fatty acids, SOFAHP = high palmitic soy oil fatty acids). Analysis of a commercial margarine sample is shown for comparison. 


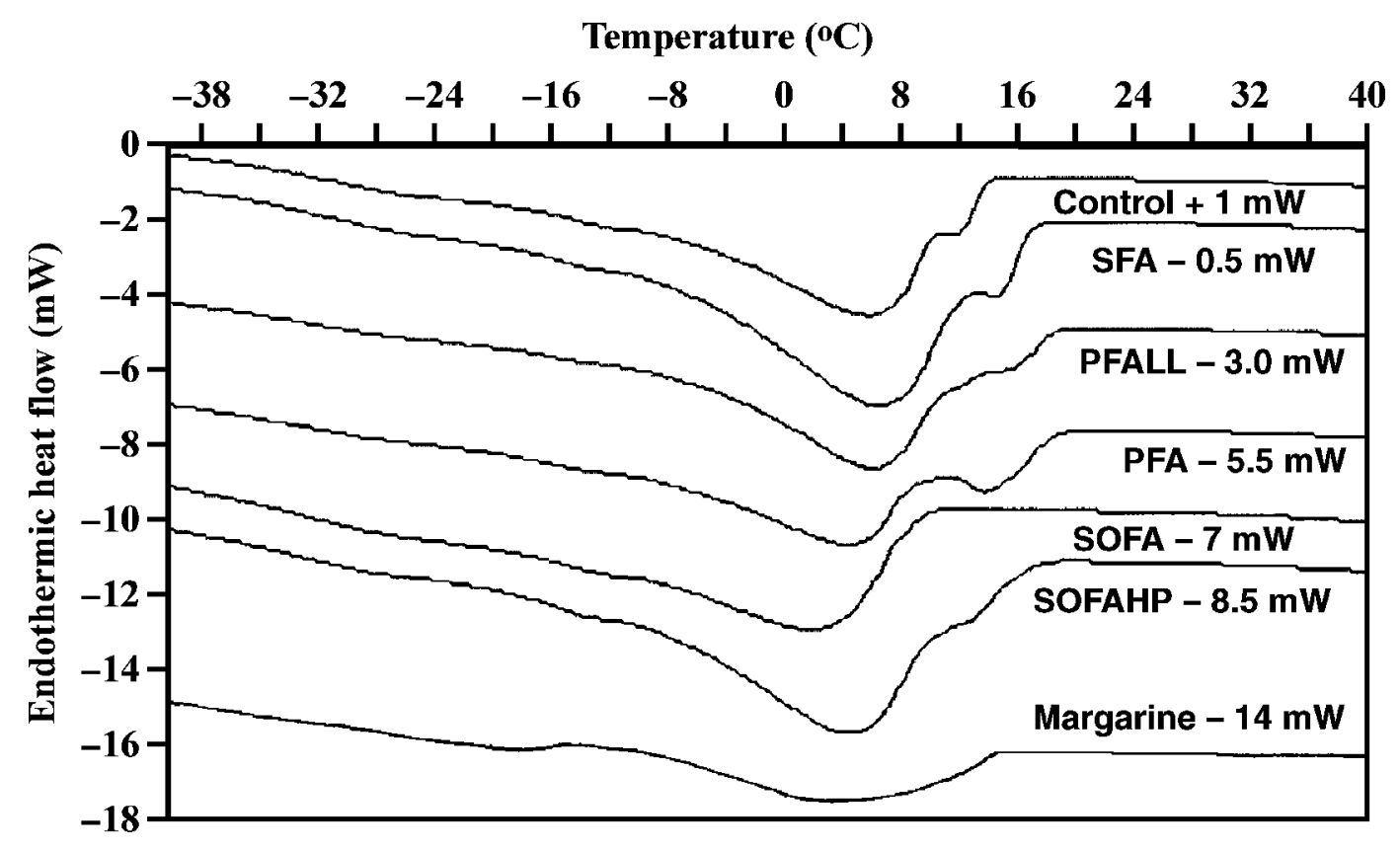

Figure 3. Shifted average cooling thermograms for butter oil samples prepared from milk of cows abomasally infused with various fatty acid treatments $(\mathrm{SFA}=$ saturated fatty acids, PFALL = low linoleic palm oil fatty acids, PFA = palm oil fatty acids, SOFA = soy oil fatty acids, SOFAHP = high palmitic soy oil fatty acids). Analysis of a commercial margarine sample is shown for comparison.

SFA did not differ from each other, whereas PFALL, PFA, SOFA, and SOFAHP had lower force of fracture and did not differ significantly from one another, even though SOFA was the least firm. The large difference between these 2 groupings possibly hindered our ability to detect statistical differences among the treatments higher in unsaturated FA. For comparison, the maximum force required to penetrate a commercial margarine sample under refrigeration conditions was only about $3 \mathrm{~N}$, demonstrating that all butters still were

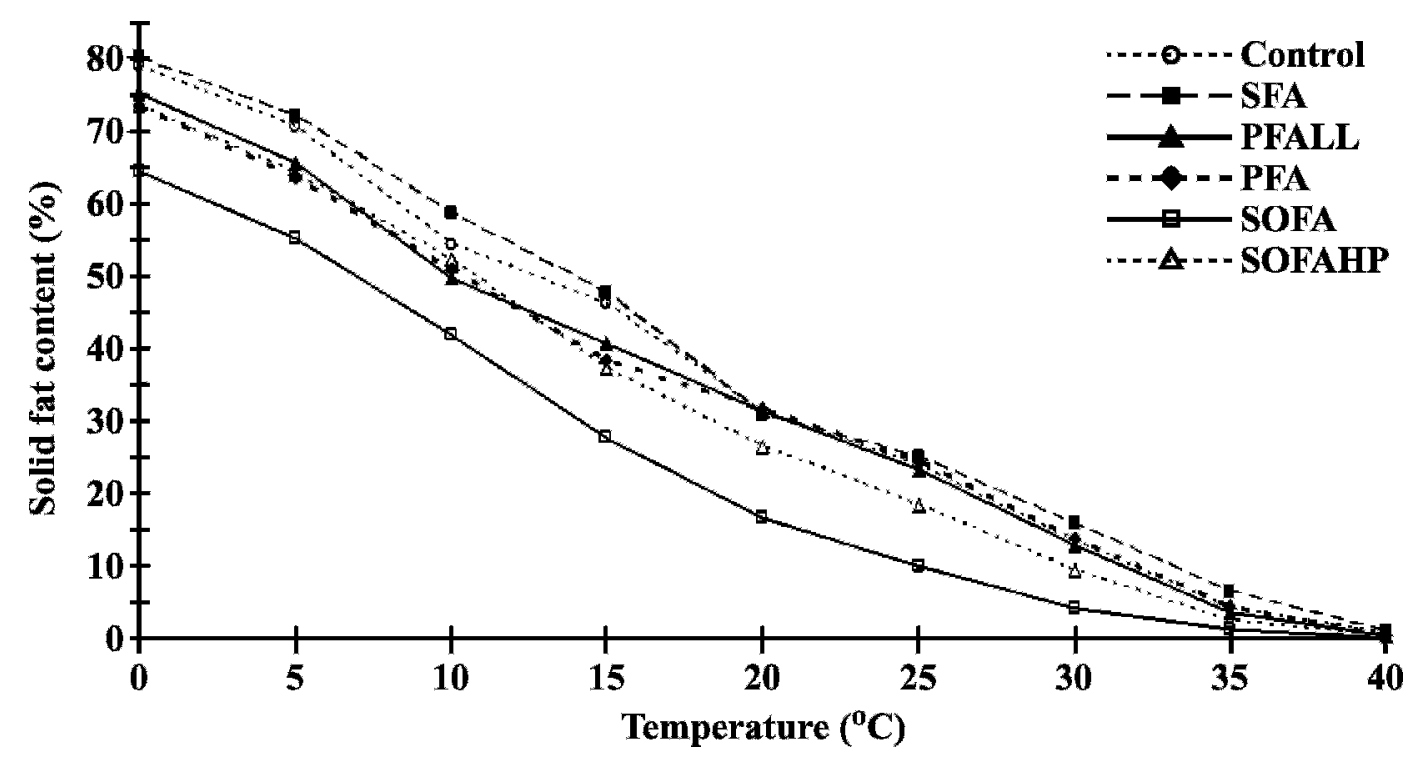

Figure 4. Solid fat content of milk fat from 0 to $40^{\circ} \mathrm{C}$ for milk fat prepared from cows abomasally infused with various fatty acid treatments $(\mathrm{SFA}=$ saturated fatty acids, PFALL = low linoleic palm oil fatty acids, PFA = palm oil fatty acids, SOFA = soy oil fatty acids, SOFAHP = high palmitic soy oil fatty acids). 


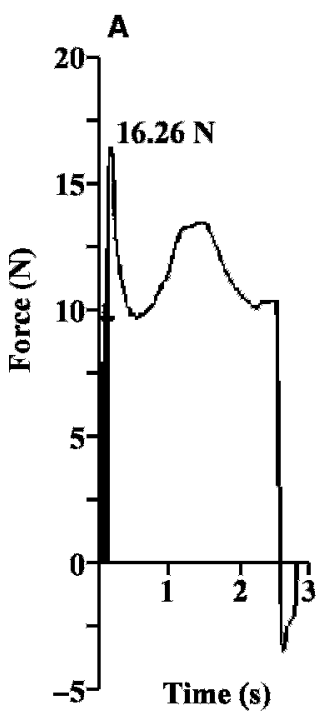

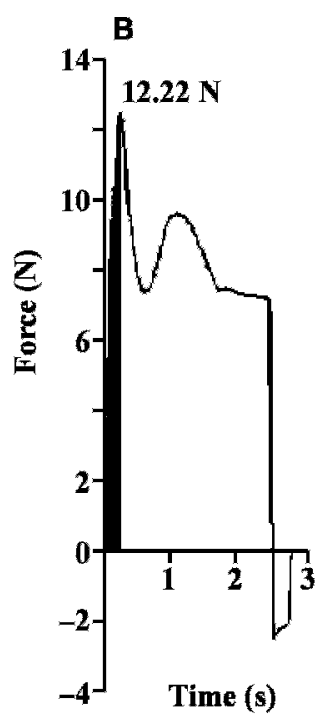

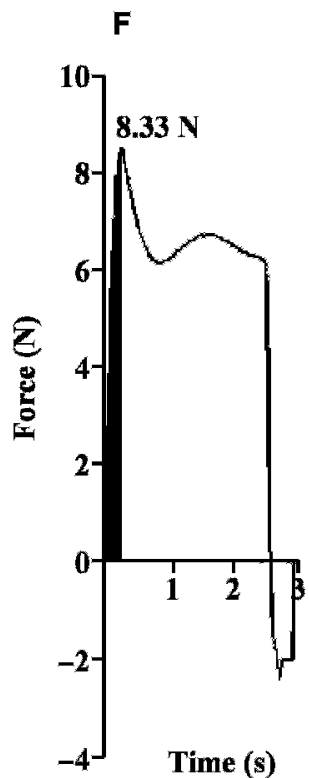

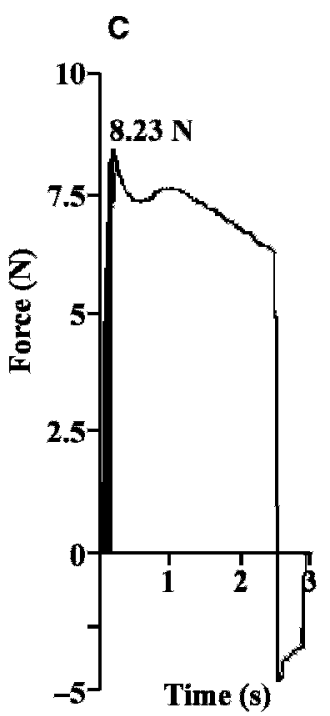
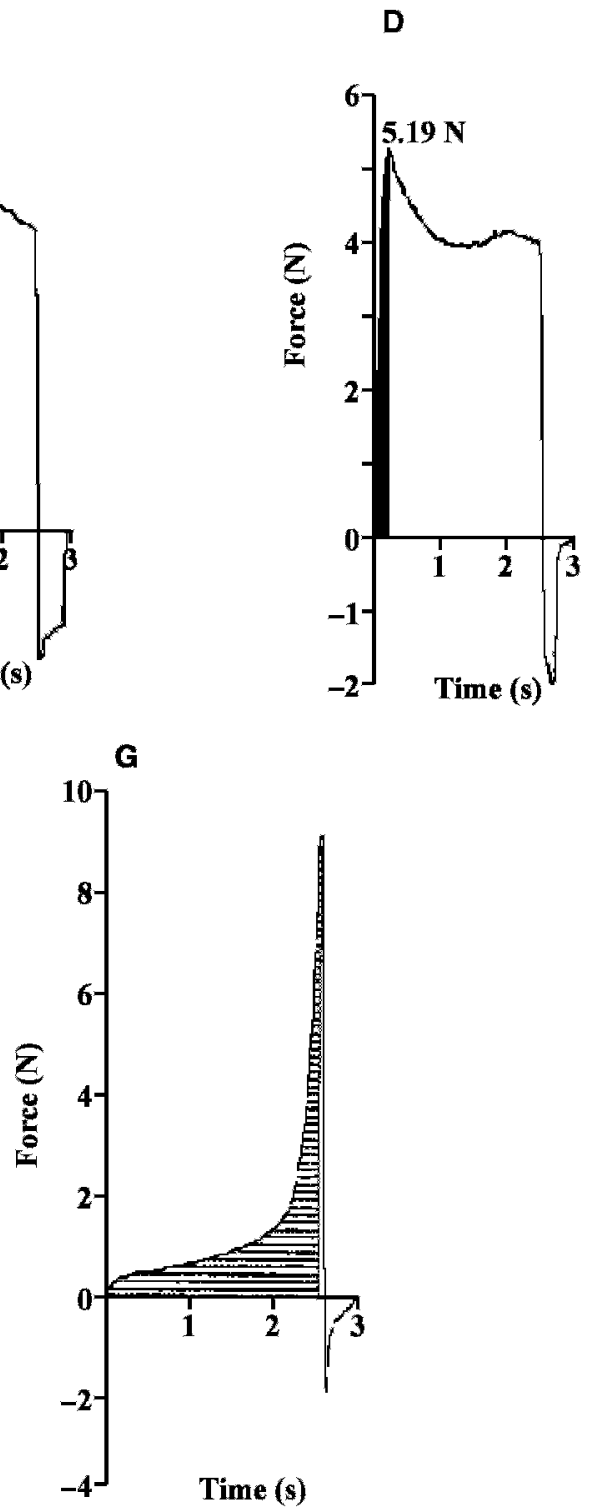

Figure 5. Comparative textural analysis of butter oils made from milk of cows infused with A) control; B) saturated fatty acids (SFA); C) low linoleic palm oil fatty acids (PFALL); D) palm oil fatty acids (PFA); E) soy oil fatty acids (SOFA); and F) high palmitic soy oil fatty acids (SOFAHP). Analysis of a commercial margarine sample $(\mathrm{G})$ is shown for comparison.

more firm than the margarine. Force of fracture was positively correlated with DSC melting point and solid fat content at $5^{\circ} \mathrm{C}$, but correlations with solid fat content were weaker and nonsignificant at higher temperatures (Table 5).

Force readings of the force-time curves were taken at the yielding point of the force curve (Figure 5). In addition to the force required to promote yielding, the shape of penetration curves also showed differences among treatments. The control (Figure 5A) showed a clear and sharp yield point shortly after the penetration of the probe, after which it dropped sharply, reflecting the characteristic brittleness of regular butter at refrigeration temperature. After this peak, a second wider peak developed, showing also the typical plasticity for regular butter fat under refrigeration conditions. For butter oil from treatment SFA (Figure 5B), the behavior at the beginning was similar to the control, but less force was required to promote yielding at the surface. The SFA butter oil also showed more brittleness, which could be attributed to the effect of the greater content of $\mathrm{C}_{18: 1 c i s-9}$ that improves fluidity because of its lower melting point. Butter oil from PFALL (Figure 5C), PFA (Figure 5D), and SOFAHP (Figure 5F) also demon- 
strated a characteristic yielding point, but compared with control and SFA, the yielding occurred at a lower force value and was less sharp. After that yielding peak, a second short and wide peak could be observed for PFALL, demonstrating a decrease in the plasticity promoted by the increased abundance of $\mathrm{C}_{18: 1 c i s-9}$ and $\mathrm{C}_{18: 2}$ compared with control and SFA treatments. Butter oil from SOFAHP also was plastic and cohesive under these conditions, displaying an increasing slope after the yielding point. For PFA, the slope after the drop of the first peak was near zero, showing fluidity but lower plasticity than PFALL and SOFAHP. The behavior for PFA likely can be explained by the lower contents of $\mathrm{C}_{16: 0}$ and $\mathrm{C}_{18: 0}$ and higher content of $\mathrm{C}_{18: 1 \text { cis-9 } 9}$ than control. Differences between PFA and PFALL may have arisen from lower $\mathrm{C}_{16: 0}$ and higher $\mathrm{C}_{18: 2}$ for PFA, and differences between PFA and SOFAHP may be attributable to greater $\mathrm{C}_{18: 1 c i s-9}$ and lower $\mathrm{C}_{18: 2}$ and $\mathrm{C}_{18: 3}$ for PFA. Finally, SOFA required the least force to promote yielding (Figure 5E) and demonstrated very low plasticity because of the higher proportion of unsaturated FA. This behavior was more similar to that of the commercial margarine sample (Figure 5G), which did not show a yielding peak but only the accumulation of force for penetration, after which the slope was constant, meaning a greater spreadability and practically no plasticity.

Correlation analysis supported the positive effects of medium-chain $\mathrm{FA}, \mathrm{C}_{18: 0}$, and $\mathrm{C}_{18: 1 \text { trans }}$ and the negative effect of $\mathrm{C}_{18: 1 c i s-9}, \mathrm{C}_{18: 2}$, and $\mathrm{C}_{18: 3}$ on butter force of fracture (Table 6). Butter force of fracture was negatively correlated with $\mathrm{C}_{26}, \mathrm{C}_{50}, \mathrm{C}_{52}$, and $\mathrm{C}_{54} \mathrm{TG}$, and positively correlated with $\mathrm{C}_{34}$ and $\mathrm{C}_{36} \mathrm{TG}$ (Table 7). These changes could be predicted based on the major FA making up those TG groups (Gresti et al., 1993). Bornaz et al. (1992) observed that $\mathrm{C}_{36}$ and $\mathrm{C}_{38}$ TG increased, whereas $\mathrm{C}_{46}$ and $\mathrm{C}_{48} \mathrm{TG}$ decreased, in winter milk fat, which was firmer than summer milk fat. Because we did not find significant correlations with TG containing predominantly $\mathrm{C}_{16: 0}$, we speculate that force of fracture is better explained by the presence of long-chain unsaturated FA and short- and mid-chain FA other than $\mathrm{C}_{16: 0}$, and $\mathrm{C}_{18: 0}$.

Our results are in general agreement with those of Munro et al. (1978), Bumbalough (1989), Enjalbert et al. (1997, 2000), and Couvreur et al. (2006), who found that butter spreadability can be improved by an increase in the total unsaturated FA content of the fat or by removal of the mid-melting fraction, both of which contribute to decreased plasticity and spreadability at refrigerator temperature $\left(5^{\circ} \mathrm{C}\right)$. In our case, the highmelting fraction was decreased and the low- and midmelting fractions were extended, in general, by the increase in unsaturated FA. These changes could explain the reduction in plasticity displayed as unsaturated FA content of the treatments increased. As the percentage of low-melting fraction is increased, cold spreadability improves, but the butter may become too soft at room temperature $\left(20^{\circ} \mathrm{C}\right)$. The behavior of milk fat in the ambient conditions at which it likely will be handled is important to evaluate.

Although it might be beneficial for some applications to increase the contents of monounsaturated FA and PUFA in milk fat, our results show that large alterations cannot be achieved without a negative effect on most of the functional properties of milk fat, in which $\mathrm{C}_{16: 0}$ plays a fundamental role. At the reduced $\mathrm{C}_{16: 0}$ content of milk fat caused by treatment SOFA (21.5\%), functional properties of butter oil were more similar to those of a vegetable oil than to typical characteristics of bovine butter. The content of $\mathrm{C}_{16: 0}$, therefore, plays an important role in milk fat functional properties.

The effect of increased $\mathrm{C}_{18: 1 c i s-9}$ was confounded by the presence of increased $\mathrm{C}_{18: 1 \text { trans }}$ isomers in milk fat. Comparatively similar solid fat content was exhibited at ambient temperature $\left(20^{\circ} \mathrm{C}\right)$ for the treatment with both the highest $\mathrm{C}_{18: 11 i s-9}$ and highest $\mathrm{C}_{18: 1 \text { trans }}$ isomer contents (PFA) and treatments with lower $\mathrm{C}_{18: 1 c i s-9}$ content. The presence of the $\mathrm{C}_{18: 1 \text { trans }}$ isomer or isomers was associated with slightly lesser mid-melting and greater high-melting fractions, and thus may have counteracted some of the effect of $\mathrm{C}_{18: 1 c i s-9}$. Nevertheless, butter oil from $\mathrm{PFA}$, which had the greatest $\mathrm{C}_{18 \text { :1cis- }}$ 9 content, was reasonably spreadable at refrigeration temperatures and kept its physical shape at ambient temperature. Because the PFA treatment resulted in milk fat that exhibited the most promising behavior in terms of maintaining functional properties while potentially improving nutritional and spreadability properties, further research seems warranted to determine the optimal amount of these FA reaching the small intestine to optimize functional properties of butter. The isomers of $\mathrm{C}_{18: 1 \text { trans }}$ also deserve attention in future research, because they affected milk fat characteristics and functional properties.

\section{CONCLUSIONS}

The FA composition of milk fat can be altered by changing the profile of FA absorbed from the intestine of lactating dairy cows. We have used this approach to produce, under controlled conditions, milk fats that varied in composition and functional properties. Although the content of PUFA has important effects on butter oil functionality, a decrease in $\mathrm{C}_{16: 0}$ had more deleterious effects than an increase in unsaturated FA. Because of the negative effects of increasing the amount of PUFA on functional properties of milk fat, especially if $\mathrm{C}_{16: 0}$ is decreased, the amount of PUFA reaching the 
small intestine of cows may need to be kept to an amount that results in the most adequate functional properties for particular products and processes. Triglyceride groups most closely associated with negative effects on functional properties of butter oil were those having short-chain FA, medium-chain FA, and PUFA $\left(\mathrm{C}_{28}, \mathrm{C}_{30}, \mathrm{C}_{38}\right.$, and $\left.\mathrm{C}_{40}\right)$, whereas $\mathrm{TG}$ enriched in $\mathrm{C}_{14: 0}$ and $\mathrm{C}_{16: 0}\left(\mathrm{C}_{44}, \mathrm{C}_{46}\right.$, and $\left.\mathrm{C}_{48}\right)$ were positively associated with functionality of butter oil. Based on our results it seems necessary to maintain $\mathrm{C}_{16: 0}$ content in milk fat to ensure that butter maintains its desired functional properties.

\section{ACKNOWLEDGMENTS}

The authors thank Milk Specialties Co. (Dundee, IL) for donating the SFA and meat solubles, and Henkel Corp. (Cincinnati, OH) for supplying the other FA mixtures. The authors are grateful to S. Younker and M. Piepenbrink for feeding and care of cows used in the experiment, and to L. Emmert and T. Cicela for laboratory assistance. The authors thank S. Taylor for assistance with TG analysis of milk fat.

\section{REFERENCES}

Ali, A. R. M., and P. S. Dimick. 1994. Thermal analysis of palm midfraction, cocoa butter and milk fat blends by differential scanning calorimetry. J. Am. Oil Chem. Soc. 71:299-302.

AOAC. 1995. Official Methods of Analysis. 15th ed. Association of Official Analytical Chemists, Arlington, VA.

AOCS. 1998. DSC melting properties of fats and oils. AOCS Recommended Practice Cj 1-94. Official Methods and Recommended Practices of the AOCS. 5th ed. American Oil Chemists Society, Champaign, IL.

Ashes, J. R., S. K. Gulati, and T. W. Scott. 1997. Potential to alter the content and composition of milk fat through nutrition. J. Dairy Sci. 80:2204-2212.

Badings, H. T., S. Tamminga, and J. E. Schaap. 1976. Production of milk with a high content of polyunsaturated fatty acids. 2 . Fatty acid composition of milk in relation to the quality of pasteurized milk, butter, and cheese. Neth. Milk Dairy J. 30:118-131.

Banks, W. 1991. Possibilities of changing milk fat composition by feeding. Utilizations of milk fat. IDF Bull. 260, Int. Dairy Fed., Brussels, Belgium.

Banks, W., J. L. Clapperton, D. D. Muir, and A. K. Girdler. 1989. Whipping properties of cream in relation to milk composition. J. Dairy Res. 56:97-105.

Bonanome, A., and S. M. Grundy. 1988. Effect of dietary stearic acid on plasma cholesterol and lipoprotein levels. N. Engl. J. Med. 318:1244-1248

Bornaz, S., G. Novak, and M. Parmentier. 1992. Seasonal and regional variation in triglyceride composition on French butterfat. J. Am. Oil Chem. Soc. 11:1131-1135.

Boudreau, A., and J. Arul. 1993. Cholesterol reduction and fat fractionation technologies for milk fat: An overview. J. Dairy Sci. 76:1772-1781.

Bremmer, D. R. 1995. Effects of infusing long-chain fatty acid mixtures similar in chain length and varying in amount of linoleic acid into the abomasum of lactating dairy cows. MS Thesis. University of Illinois, Urbana.

Bremmer, D. R., L. D. Ruppert, J. H. Clark, and J. K. Drackley. 1998. Effects of chain length and unsaturation of fatty acid mixtures infused into the abomasum of lactating dairy cows. J. Dairy Sci. 81:176-188.

Bumbalough, J. E., inventor. 1989. Spreadable product having anhydrous milk fat component. Wisconsin Milk Marketing Board, assignee. US Pat. No.4,840,190.

Chilliard, Y., A. Ferlay, and M. Doreau. 2001. Effect of different types of forages, animal fat or marine oils in cow's diet on milk fat secretion and composition, especially conjugated linoleic acid (CLA) and polyunsaturated fatty acids. Livest. Prod. Sci. 70:31-48.

Chilliard, Y., A. Ferlay, R. M. Mansbridge, and M. Doreau. 2000. Ruminant milk fat plasticity: Nutritional control of saturated, polyunsaturated, trans and conjugated fatty acids. Ann. Zootech. 49:181-205.

Chouinard, P. Y., V. Girard, and G. J. Brisson. 1998. Fatty acid profile and physical properties of milk fat from cows fed calcium salts of fatty acids with varying unsaturation. J. Dairy Sci. 81:471-481.

Couvreur, S., C. Hurtaud, C. Lopez, L. Delaby, and J. L. Peyraud. 2006. The linear relationship between the proportion of fresh grass in the cow diet, milk fatty acid composition, and butter properties. J. Dairy Sci. 89:1956-1969.

DeMan, J. M. 1961. Physical properties of milk fat. 1. Influences of chemical modification. J. Dairy Res. 28:81-86.

DePeters, E. J., J. B. German, S. J. Taylor, S. T. Essex, and H. PerezMonti. 2001. Fatty acid and triglyceride composition of milk fat from lactating Holstein cows in response to supplemental canola oil. J. Dairy Sci. 84:929-936.

Enjalbert, F., M. C. Nicot, C. Bayourthe, and R. Moncoulon. 2000. Effects of duodenal infusions of palmitic, stearic, or oleic acids on milk composition and physical properties of butter. J. Dairy Sci. 83:1428-1433.

Enjalbert, F., M. C. Nicot, C. Bayourthe, M. Vernay, and R. Moncoulon. 1997. Effects of dietary calcium soaps of unsaturated fatty acids on digestion, milk composition and physical properties of butter. J. Dairy Res. 64:181-195.

Fearon, A. M. 1988. A study of some factors contributing to the rheological properties of butter. Thesis. Queen's University, Belfast, UK.

Fearon, A. M., C. T. Charlton, and D. J. Kilpatrick. 1994. A further investigation of the influence of dietary protected lipid supplements on the characteristics of cows' milk fat. J. Sci. Food Agric. 66:247-256.

German, J. B., and C. J. Dillard. 1998. Fractionated milk fat: Composition, structure, and functional properties. Food Technol. $52: 33-38$.

Gresti, J., M. Bogaut, C. Maniongui, and J. Bezard. 1993. Composition of molecular species of triacylglycerols in bovine milk fat. J. Dairy Sci. 76:1850-1869.

Grummer, R. R. 1991. Effect of feed on the composition of milk fat. J. Dairy Sci. 74:3244-3257.

Hillbrick, G., and M. A. Augustin. 2002. Milkfat characteristics and functionality: Opportunities for improvement. Aust. J. Dairy Technol. 57:45-51.

Jensen, R. G., A. M. Ferris, and C. J. Lammi-Keefe. 1991. The composition of milk fat. J. Dairy Sci. 74:3228-3243.

Kaylegian, K. E., R. W. Hartel, and R. C. Lindsay. 1993. Applications of modified milk fat in food products. J. Dairy Sci. 76:1782-1796.

Kaylegian, K. E., and R. C. Lindsay. 1994. Handbook of Milkfat Fractionation Technology and Application. AOCS Press, Champaign, IL.

Kermasha, S., S. Kubow, M. Safari, and A. Reid. 1993. Determination of the positional distribution of fatty acids in butterfat triacylglycerols. J. Am. Oil Chem. Soc. 70:169-173.

Lin, M. P., C. R. Staples, C. A. Sims, and S. F. O'Keefe. 1996. Modification of fatty acids in milk by feeding calcium-protected high oleic sunflower oil. J. Food Sci. 61:24-27.

Lopez, C., P. Lesieur, C. Borgaux, and M. Ollivon. 2005. Thermal and structural behavior of anhydrous milk fat. 3. Influence of cooling rate. J. Dairy Sci. 88:511-526.

Michalski, M. C., M. Ollivon, V. Briard, N. Leconte, and C. Lopez. 2004. Native fat globules of different sizes selected from raw milk: 
Thermal and structural behavior. Chem. Phys. Lipids 132:247261.

Middaugh, R. P., R. J. Baer, D. P. Casper, D. J. Schingoethe, and S. W. Seas. 1988. Characteristics of milk and butter from cows fed sunflower seeds. J. Dairy Sci. 71:3179-3187.

Mulder, H., and P. Walstra. 1974. The milk fat globule: Emulsion science as applied to milk products and comparable foods. Center Agric. Publ. Documents, Wageningen, the Netherlands.

Munro, S. D., T. G. Bissell, R. S. Jebson, R. Norris, and M. W. Taylor. 1978. The production of a more spreadable butter by solvent crystallization of milk fat. Page 862 in Proc. 20th Int. Dairy Congr., Int. Dairy Congr., Paris, France.

Noakes, M., P. J. Nestel, and P. M. Clifton. 1996. Modifying the fatty acid profile of dairy products through feedlot technology lowers plasma cholesterol of humans consuming the products. Am. J. Clin. Nutr. 63:42-46.

O'Donnell, J. A. 1989. Milk fat technologies and markets: A summary of the Wisconsin Milk Marketing Board 1988 milk fat round table. J. Dairy Sci. 72:3109-3115.

Palmquist, D. L., A. D. Beaulieu, and D. M. Barbano. 1993. Milk fat synthesis and modification. Feed and animal factors influencing milk fat composition. J. Dairy Sci. 76:1753-1771.

Parthasarathy, S., J. C. Khoo, E. Miller, J. Barnett, L. Witztum, and D. Steinberg. 1990. Low density lipoprotein rich in oleic acid is protected against oxidative modification: Implications for dietary prevention of artherosclerosis. Proc. Natl. Acad. Sci. USA 87:3894-3898.

Precht, D., E. Frede, and H. Timmsen. 1984. Effect of feeding on the milk fat composition. Page 69-73 in Milk Fat and Its Modifications. Proc. 14th Scandinavian Forum for Lipid Res. Technol. R. Marcuse, ed. Lipidforum, Gottenberg, Sweden.

Shi, Y., C. M. Smith, and R. W. Hartel. 2001. Compositional effects on milk fat crystallization. J. Dairy Sci. 84:2392-2401.

Stegeman, G. A., R. J. Baer, D. J. Schingoethe, and D. P. Casper. 1992. Composition and flavor of milk and butter from cows fed unsaturated dietary fat and receiving bovine somatotropin. J. Dairy Sci. 75:962-970.

Sukhija, P. S., and D. L. Palmquist. 1988. Rapid method for determination of total fatty acid content and composition of feedstuffs and feces. J. Agric. Food Chem. 36:1202-1206.

Wilke, M. S., and M. T. Clandinin. 2005. Influence of dietary saturated fatty acids on the regulation of plasma cholesterol concentration. Lipids 40:1207-1213.

Wong, W., P. Jelen, and J. M. DeMan. 1982. Softening of butter related to feeding low doses of protected tallow supplement. J. Dairy Sci. 65:1632-1638.

Woodside, J. V., and D. Kromhout. 2005. Fatty acids and CHD. Proc. Nutr. Soc. 64:554-564. 